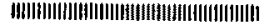

抄

録



部

門
航空榙一般

ヘリコフタ

\title{
空氞力学
}

\section{1. 平衡状慜にない解唯気体の力学の最近の進歩}

Recent advances in nonequilibrium dissociating gas dynamics. T.Y.Li. ARS J. 31, 2 (1961/2) 170178. この翊文は化学反応の影帮を含んだ気体の力 学の現在までのいろいるな研究を概観することを目的 としている. そのためにまず化学反态の熱力学の一般 的な概念の简単な説明を行ないつぎにいくつかの実際 の気体の流れに对して今まで行なわれた理論的解析に いてその取り扱い方, 問題点, さらに今後の研究の すすめ方等についてやや詳しくのへている，以下順を 追っでこれらの内容を紹介する. 最初に樊力学の問題 としては反応を伴う気体の特徴として化学ポテンシャ ルが導入されその結果熱力学の第一法則はつぎのよう にかかれる. $T d s=d h-(1 / \rho) d p-\Sigma \mu_{i} d c_{i} こ こ に T$, $\rho, p$ はそれぞれ気体の温度、密度, 王力, $c_{i}, \mu_{i}$ は化 学種：の貲地および化学ポテンシャル， $s, h$ は土ン トロビーおよびェンタルピーとする.つぎに流れの場 は周知の量，運動量およびェネルギーの各保存則て 記述されるが，この論文では特に粘性，熱伝導および拡 散をすへて省略している．つぎに反応を特徽づける反 応速度の式が与えられ問題が完結される.ここて注意 すべことは流れの場の渦度や徝環が反応に影慗され ることである.つぎに流れの場の解析の実例に進む. この際一般に平衡状態にない反応の考察は極めて困難 なため種々の仮定を行なう．まず以下の実例ではすべ て Lighthill の提唱した解離だ考えた理想気体 (ideal dissociating gas) の model を対象とする. 第 1の例は音波の伝播の場合反心によって absorption お よび dispersion のあらわれることを示している. 第 2 の例は線形理猃を用いて単純臆非波の解析の結果物体 面上の圧力は反忘力平衡てない領域にわたって变化す ることを示している.つぎに非線形方程式を扱う場合 の特性曲線法を二次元お゙よび軸対称三次元流について 一般的に説明し最後にこの論文の中で著者の研究にな る nozzle 内の流れについて特に流れの場を支配する ハランータについてやや詳しくのへ，ついて現在数多 くの研究が見られる鈍磌物体のよどみ点近くの流れの 解析の詳細な磁明を行なっている。この論文を終える に当たって都者はつぎの点すなわち（1）Lighthill の gas model は解析の手段として有用なこと（2）反忘 の速度常数 (rate constant) の理猃および実験の両面 からの研究の重要なことをのへている.なお参考文献



が数多く記载されているのでこの方面に興味をむつ研 究者には非常に有用な論文てあることを最後につけく わえたい.

(川又 慎)

\section{材料}

2. Titan の推進装置の工作法

Fabricating the Titan propulsion system. W.M. Boam Metal Progress 79, 3 (1961/3) 83-87. ICBM Taitanは, ケロシンと液体酸素を燃料としているか，推進装置は 燃焼室の極端な高温から極低温の酸化剂の影響まて考 虑しなければならない，したがって材料の選択には非 常に多くの問題が含まれて来る. 燃焼室は, 前もって 成形した多数の 0.020 in 厚の 347 ステンレスの管を 集めて，砂時計の漏斗型に螆付して作る. 燃料はこの 管の中を循環して然焼室を冷却する. ステンレス管の 爵付は，密閉したレトルト内で乾燥水素を通して行な う.レトルト内にアルゴンと水素を交互に流して完全 な水素第囲気にした後，ベル炬を上にかぶせて 1,000

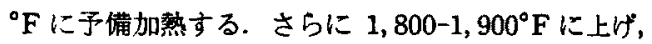

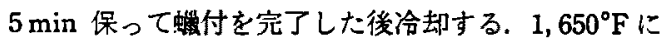
達した時ベル炉を除き，水冷装置をレトルトにかぶせ て急冷する.この間 $600^{\circ} \mathrm{F}$ に達するまて水素を流し 続け，ついてアルゴンで置換して室温に達する. 酸化

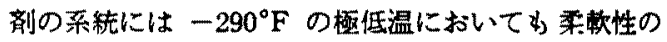
ある材料が要求される.このためには， $\mathrm{Ni}, \mathrm{Cu}, \mathrm{Al}$ な どが最か適しているが，Ni を含さ低合金鋼あるいは 17-7 PH, AM 350 ステンレスなども適している. 然 料系統は酸化用の系統のように特別な低温特性は必要 ではないが，工程の筆純化と経済的な点からはどちら も同じ材料を用いる方が良い.ターボポンプは，347 ステンレス製の inlet, N-155 製のノズル, Hayne Stellite 21 製のブレード, A-286 䌘の diskなどを蝩 付によって組み立てる.

酸化郕の系統の static なシールには perfluorinated polymer が，また dynamic なシールには polychlorotrifluoethylene が遟している. 然料系統には，一般の ジェット・エンシンンに使用されるのと同しょうに dynamic なシールにはナイロンおよび polychlorotrifluoethylene $か *$, static なシールには perfluorinated polymer が適している. Buna-N elastmer はいずれの シールにむ用いることがでる。

第 2 段のエンシンンは ablative skirt が用いられて いる. これは最初フェノリック・レジンを浸したアス (149 其へつつく) 
代表する值 $\rho^{\prime \prime}$ て置き換えるだりて最大忍力の近似值 が得られるであろう。

$\rho^{\prime} \rho^{\prime \prime}$ の決定は簡単ではないし，二三の資料むある が広くばらついているのて、今後の研究にまた杖ばな らない:これらの値が合理的に決定されたならば，本 譣文の結果がクラックを有する薄板構造の静強度や補 強板における波労クラックの進展等の研究を推進する ことが期待される．また $\rho^{\prime}, \rho^{\prime \prime}$ の值が不明確な場合 です，とにかくこれらは材料によって定まる量である と考之られるから，種々の補強材の効果を定性的に比 較するような場合には第 1 表，第 3 図を直接議論の根 拋とすることがてきる。なお引䋨き，任意の曲げ剛性 引こ張り㓮性をむつ補強材て補強した带板や，多数な 平行な補強材を有する無限板におけるクラックによる 虑力集中の解析も行ないつつあるので，完了次第報告 する予定である。

論文を終わるにさいし，数值計算に協力された当研 究所の飯田宗四郎技官に深謝する。

\section{考交 献}

1) G. R. Irwin "Fracture" Pre-publication copy of Vol. V article in Handbuch der Physik, 1958.

2) A.A. Griffith "The Phanomenon of Rupture and Flow in Solids" Phil. Trans. Roy. Soc. London. Ser. A, Vol. 221, pp. 168 198, 1920.

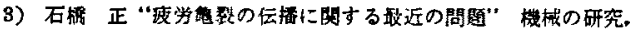
10 * 5 号, pp. 609 615, 1958.

4) R.C. J. Howland "On the Stresses in the Neighbourhood of a Circular Hole in a Strip Under Tension" Phil. Trans. Roy. Soc. London, Ser. A. Vol. 229, pp. $56 \sim 57,1930$.

5) 同上, D. 58

6) 同上. p. 59 60. ただし $E_{2 p}, L_{2 p}$ はそれぞれ本諭文の $F_{2 p} 2$ ，

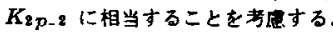

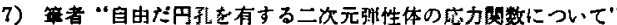

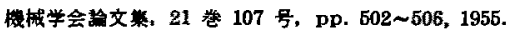

8) P. Rabinowitz \& G. Weiss "Tables of Abscissas and Weights for Numerical Evaluation of Integrala of the Form $\int_{0}^{\infty} e^{-x^{n}} f(x) d x^{*}$ Mathematical Tables and Other Aide to Computation, Vol. 18, pp. 285 294, 1959.

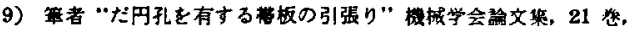
107 号, p. 609, 式 (17), 1955.

10) 同上, p. 511, 式 (31)

11) H. M. Westergaard "Bearing Preasure and Cracks" J. Appl. Mech., Vol. 6, No. 2, p. A-49, 1939 . また交献 1). p. 2.17 .

12) H. Neuber "Kexbspannungslehre" pp. 146 148, 1937 .
(172 頁よりっつく)

ベストテープを，マンドレルに $45^{\circ}$ の角度で巻き付


作る、重合完了後，所定の寸法に機械仕上げして，さら にフェノリック・レシン含浸のグラス・クロスを巻き 付ける.この外側にファイパー・グラスのハニカム構 造の層を作って一層強化したものをアルミニウムのフ ランジによって㜣烧室に固定する：【注，女中の合金 の組成. 347 (ステンレス銅) : Cr 17-19\%, Ni 9-13 $\%$, Mn 2\%, Si 1\%, C 0.08\%, Fe Bal. 17-7 PH ( ス テンレス鎆) : Cr 17\%, Ni $7 \%$, Mn 0.7\%, Si 0.4
$\%$, C 0.07\%, Fe Bal. AM 350 (ステンレス鋼) : Cr $16.5 \%$, Ni $4.25 \%$, Mo $2.75 \%$, Mn $0.75 \%$, Si $0.35 \%$, C $0.10 \%$, Fe Bal. N-155 (耐熱合金) : Cr $21 \%$, Ni $20 \%$, Co $20 \%$, Mo $3 \%$, W $3 \%$, Cb $1 \%$, $\mathrm{Mn} 1.5 \%, \mathrm{Si} 0.5 \%, \mathrm{C} 0.15 \%, \mathrm{Fe}$ Bal. Haynes Stellite 21 (耐㪇合金): $\mathrm{Cr} 27 \%, \mathrm{Ni} 3 \%$, Mo $5 \%$, Fe $1 \%$, Mn 0.6\%, Si 0.6\%, C $0.25 \%$, Co Bal. A-286 (耐熱合金): Ni 26\%, Cr 15\%, Mo $1.25 \%$, Ti $2 \%$, Al $0.2 \%$, V $0.3 \%$, Mn $1.35 \%$, Si $0.5 \%$, C $0.05 \%$, Fe Bal.] （小原 嗣朗）

\section{表 紙写亨 说 明}

航空技術研究所に昭和 36 年 7 月完成した吹き出し 式超音速風胴の测定部付近を示す写真である.

本風胴は川崎重工業株式会社を主契約として去る昭 和 34 年 12 月起工したものて本研究所の眼設高圧貯 気槽，乾燥空気製造設備およびデータトロン 205 型電 子計算機等と連結して使用される。

内径 $10 \mathrm{~m} の 2$ 基の貯気槽から出た空気は調圧并に より集合胴で一定王に制御されさらに可暁ノズルを通
り測定部に超音速流を生した後搪散䏤，消音器を程て 大気に放出される. 写真の測定部のシュリーレン写真 用密の直径は $650 \mathrm{~mm}$ で片側は取り外してフラッター 試験用模型出入装置が取り付けられまたフラッタ一試 験のために風胴连転中に気流の全圧あるいはマッ八数 をある程度変化てきるようにしてある。

主要要目 圧縮機 1,200P，充填時間約 $2.2 \mathrm{~h}$, 测定 部断面 $1 \mathrm{~m} \times 1 \mathrm{~m}$, マッ八数 $1.4 \sim 4.0$ 持䊦時間 $30 \mathrm{~s}$ 以上.

（航技研 高木広治） 